\title{
Control of LTR transcription by SWI/SNF BAF and PBAF complexes
}

\author{
Irene Guendel ${ }^{1}$, Rachel Van Duyne ${ }^{1,2}$, Fatah Kashanchi ${ }^{12^{*}}$ \\ From 16th International Conference on Human Retroviruses: HTLV and Related Viruses \\ Montreal, Canada. 26-30 June 2013
}

The transcription of HTLV-1 LTR is a highly regulated process by the organized chromatin structure within a cell's nucleus; chromatin is folded into compact fibers (30-400 $\mathrm{nm}$ thick), which physically prevents the accessibility of cellular promoters by transcriptional machinery. A variety of enzymes and protein complexes are present in the cell to mediate the opening" and "closing" of chromatin structure to allow for viral and cellular processes to occur. This chromatin remodeling occurs through two major mechanisms: covalent epigenetic modifications of $\mathrm{N}$-terminal histone tails and ATPdependent chromatin remodeling complexes (CRCs). HTLV-1 Tax has been shown by us and others to effectively regulate both steps. Here, we will discuss the effect of BAF and PBAF using a series of siRNA experiments for both basal and activated transcription. We observed that BAF complexes are regulated by phosphorylation of Baf 53 subunit (possibly by pTEF-b) and PBAF complexes substitute the negative inhibitory BAF complexes needed for activated transcription. We believe that Baf 53 activity is through closing of the chromatin structure at the transcription start site and that PBAF is able to aid in elongation by communicating with $\mathrm{p} 300 / \mathrm{PCAF}$ and histone acetylated tails. Implications of these complexes in transcription for both viral and cellular genes will be discussed.

\section{Authors' details}

'School of Systems Biology, National Center for Biodefense \& Infectious Diseases, George Mason University, Manassas, Virginia, USA. ${ }^{2}$ Department of Microbiology, Immunology, \& Tropical Medicine, The George Washington University Medical Center, Washington, D.C., USA.

Published: 7 January 2014

\footnotetext{
* Correspondence: fkaschanc@gmu.edu

'School of Systems Biology, National Center for Biodefense \& Infectious

Diseases, George Mason University, Manassas, Virginia, USA

Full list of author information is available at the end of the article
}

doi:10.1186/1742-4690-11-S1-047

Cite this article as: Guendel et al:: Control of LTR transcription by SWI/ SNF BAF and PBAF complexes. Retrovirology 2014 11(Suppl 1):047.
Submit your next manuscript to BioMed Central and take full advantage of:

- Convenient online submission

- Thorough peer review

- No space constraints or color figure charges

- Immediate publication on acceptance

- Inclusion in PubMed, CAS, Scopus and Google Scholar

- Research which is freely available for redistribution

Submit your manuscript at www.biomedcentral.com/submit

\section{() Biomed Central}

C Biomed Central

(c) 2014 Guendel et al; licensee BioMed Central Ltd. This is an Open Access article distributed under the terms of the Creative Commons Attribution License (http://creativecommons.org/licenses/by/2.0), which permits unrestricted use, distribution, and reproduction in any medium, provided the original work is properly cited. The Creative Commons Public Domain Dedication waiver (http://creativecommons.org/publicdomain/zero/1.0/) applies to the data made available in this article, unless otherwise stated. 